\title{
Technologies of Displacement and Children's Right to Asylum in Sweden
}

\author{
Anna Lundberg ${ }^{1} \cdot$ Jacob Lind $^{1}$
}

Published online: 10 January 2017

C The Author(s) 2017. This article is published with open access at Springerlink.com

\begin{abstract}
Through an analysis of 100 asylum decisions and 10 interviews with 20 asylum officers at the Swedish Migration Agency this article reveals two intricate processes through which children's rights are displaced in the Swedish asylum process; by overlooking children's individual claims for asylum through a circle of neglect, and negating children's best interests. The article demonstrates how the balancing act between migration control on one hand and children's rights on the other hand plays out in the asylum process, which results in a double displacement; the children are not adult enough to be addressed as asylum seekers and not children enough to deserve qualification as bearer of children's rights. An in-depth analysis of everyday practices at institutions applying children's rights is essential both to understand the reproduction of discrepancies between rights on paper and rights in practice, and to explore the potential of rights to disrupt oppressive vehicles of power.
\end{abstract}

Keywords CRC $\cdot$ Children's rights $\cdot$ Asylum $\cdot$ Negation $\cdot$ Migration control $\cdot$ Deportation regime

Sweden is perceived as a pioneer in the struggle for children's rights (Freeman 2000: 287; Shamseldin 2012: 94). The country has also gained attention for its correct asylum process (Feijen and Frennmark 2011) and long tradition of liberal immigration policies (Andersson 2012:125f, Emilsson 2014). In recent years, the debate around children's rights in Sweden has centred around whether the Convention on the Rights of the Child (CRC) should be incorporated into national law, meaning that the CRC as a whole would get the status of law, compared to how the treaty currently and continuously is

Anna Lundberg

anna.lundberg@mah.se

Jacob Lind

jacob.lind@mah.se

1 Faculty of Culture and Society, Global Political Studies, Malmö University, Malmö, Sweden 
partly transformed into Swedish regulations through the adding of a few articles of the convention to existing paragraphs. This way, the 'best interests of the child-principle' (CRC art 3, hereinafter the best-interests principle) was transformed into the Swedish Act in 1997 as, a general overarching principle [portalparagraf].

In 2013, the previous centre-right 'Alliance' government commissioned a state investigator to enquire into what consequences a full incorporation of the CRC could have (Regeringen 2013). We, the authors, were appointed by said investigator to conduct a study about how the CRC was applied in the use of current asylum law, specifically in relation to children in families. It is on the basis of this review that the findings of the present article are based. When the Alliance lost the election in 2014, the new current left-green government immediately assured that the complete CRC would be incorporated. In March 2016, the state investigator presented the final report, including our study, to the government (Regeringen 2016a).

With relatively well functioning and strong public institutions and a confident selfimage and reputation of respecting international law, Sweden is arguably a 'critical case' (Flyvbjerg 2001:77f). It is useful to study the asylum process in Sweden not as an 'ideal' form of bureaucracy, but rather as an expression of 'the best there is' in western nation states. In this way, the case of Sweden arguably offers an insight into the potential children's and refugees' rights, and their related legal conventions, have at this specific political and historical time in history to influence state practice on who is worthy of inclusion under the confines of western welfare states.

In the asylum process, this worthiness is further brought to a head since it lies at the heart of the state's 'deportation regime' (Peutz and De Genova 2010: 4). More specifically, here the balancing act between inclusion through residence permit and exclusion through deportation manifests itself. By the deportation regime we mean all those socialised state practices in the contemporary world aiming to separate who should belong to, and who should be deported from the state. As noted, these practices are continually and inevitably embedded in assessments of asylum claims. In the contemporary world, deportation is also increasingly used as a method through which states manage populations and through which they prove their efficiency.

The aim of this article is to discuss how the Swedish asylum process becomes a key space of the 'deportation regime' through an analysis of how the inevitable tension that characterizes any debate about children's rights, asylum and immigration - namely on the one hand the interest of the sovereign to keep immigration numbers down and, on the other hand, the interests of asylum seeking children, potentially deportable, to enjoy permanent residence - plays out in everyday work at the Swedish Migration Agency. While our primary aim is not to provide an answer to whether an incorporation of the CRC could have any actual effects in regard to improving asylum-seeking children's opportunity for residence permit, the answer to this question is nonetheless in part related to how the state's interest in keeping immigration down is weighed against children's rights. Since the issue is also discussed as a potential, at least partial, 'solution' to the question of how children's rights could be implemented in general, it will briefly also be addressed in relation to our conclusions of the present study. The article thus takes a socio-legal approach where law is regarded as contrived through practice (McLeod 2010; Priban 2002).

In previous research, the first author has investigated children's rights in action and demonstrated how, for example, the best interests-principle tends to be used in 
contradiction of asylum seeking children's interests (Lundberg 2011; Ottosson and Lundberg 2013). This article continues this discussion further through a deeper understanding of the everyday practice of applying children's rights on the micro-level as a context that is key to the 'deportation regime'. With the concept 'micro-level', we refer to the intricate, everyday practices and discourses that influence, impregnate and enable the work of asylum officers during the process of making asylum decisions. Through this approach, we argue, examples were revealed of practices that may be understood as technologies of displacement of children's rights in the deportation regime. Inspired by Anna Holzscheiter's (2010) and Ann Quennerstedt's (2013) argument that children's rights research would benefit from a higher degree of contextualisation and theorization (also see Boyden 1997 for historical context), this study explores practices of displacement of rights, in the Swedish asylum process. Analysing children's rights in this context is not only one important key to understand reproductions and maintenance of discrepancies between rights on paper and rights in practice but is also a way to understand deportation as an increasingly widespread and technocratic state-man craft of the current world. Furthermore, our analysis provides for an exploration of rights' potential radical capacity to disrupt oppressive vehicles of power.

The article continues below with a theoretical section engaging in the literature on potential effects of an incorporation of the CRC and a discussion on various ways critical scholars have tried to understand the phenomenon of the exclusionary practice of asylum as a central element in the deportation regime. Then, our methodological considerations including our material are presented, as well as our applied mixed method approach. The following analysis of how children's rights are constructed at the Migration Agency focuses on written reasoning around children's rights in asylum decisions as well as the organisational and institutional context through our interviews. In the analysis, we highlight how children's own claims for asylum are overlooked through a 'circle of neglect' and the pervasive use of negations when assessing children's best interests in asylum cases. We conclude with a discussion on what these technologies of displacement tell us about how the deportation regime is reproduced, and emerges, in a local context of asylum assessments. Lastly, the study's findings are related to the potential of the $\mathrm{CRC}$ in limiting the sovereignty of states in general and the magnitude of the deportation regime in particular.

\section{The Domestic Effects of the CRC}

The issue of the domestic effects of the CRC in Sweden and how it relates to migrant children has been discussed by Hans E. Andersson (2012) who noted, with reference to studies of Swedish parliamentary discussions, that the significance of the CRC for domestic policies is ambivalent. Through the case of the right to health care for children who lack formal authorisation to reside in Sweden, and the rights of children to be heard and have their best interests taken into consideration in the asylum process, Andersson concluded in his study that 'when the CRC has been perceived to challenge too seriously the core of what a state is, e.g. a state's ability to control its territory through regulated immigration, the CRC has so far had to yield' (Andersson 2012, p. 139).

Would the incorporation of the CRC into Swedish law make a change in this regard? This question has become an important issue in Sweden, both for NGOs such as 
UNICEF (2016) and Save the Children (2016a, b), as well as churches (Carlshamre et al. 2014), political parties and professionals who work with children's rights. It may seem perplexing that actors spend so much energy to argue for an incorporation of the CRC, when research seems to be sceptical about what difference an incorporation will actually have for the children at stake (See Stern and Jörnrud 2011; Åhman 2011). Van Bueren for example points to the importance of lawyers and the justice system's adaptation to the international treaty and coherent attitudes, for domestic effects to come about (van Bueren 1999).

One could ask, as Andersson points to in his study with reference to Soysal (1994) and Benhabib (2004), if the public arguments by various actors for an incorporation is a matter of positioning themselves as 'globalists' who claim that international human rights treaties actually do matter and that these treaties will make a difference in turning citizen's rights to human rights? Do they wish to distance themselves from the more critical positions taken by for example Joppke (1998, 2001), who questions whether international human rights agreements can play a role at all? Regardless of what conviction one has in international treaties' ability to improve the situation of children who seek refuge, a spiteful paradox of human rights is the fact that they turn out to be as weak as they are appealing. They may be the only substantial option available for actors struggling to improve the living conditions of non-citizens in the current system. It is obvious that the sovereign, in the much referred Schmittian essence, has the privilege to make exceptions from international law when it deems it necessary (Schmitt 2005 [1922]). Also, Hannah Arendt reminds us that sovereignty is most absolute in matters of migration, naturalization, nationality, and deportation (Arendt 1973 [1951] ch. 9). Yet, in a world increasingly marked by human mobility where children constitute half of the world's refugee population (UNHCR 2015) and states provide the protection they pledge, the CRC is one of few legal means available to unsettle the power of the sovereign.

International scholars highlight the potential — at least formally — of the instrument for asylum seeking children (Goodwin-Gill and McAdam 2007; Pobjoy 2013). Jason M Pobjoy for example argues that Article 3 of the CRC could provide a basis for asylum in cases where the 1951 refugee convention is not enough. A divergent approach to the issue of children's rights and migrant children is provided by Gregor Noll (2010), who points to the weakness of the CRC, and Quennerstedt (2013, also see Reynaert et al. 2012) who highlights that children's rights research focus too much on implementing a coherent package. Regardless of what approach taken to the potential of the CRC to limit the state, the fact persists that there is an increasing tension today between the cosmopolitan rights of children on one hand and states' interest of maintaining a regulated immigration on the other.

The weakness of rights in general and the CRC in particular has become evident in Sweden in the last year when a number of legislative proposals that severely restrict immigration and compromise the rights of children, have been adopted (Regeringen 2016b). Whereas international obligations in this process have been presented as an important element to hold on to, the government maintains that the examination of 'the best interests' [of children] may not go so far that it basically becomes a separate criterion for residence permits to be a child (Regeringen 2016c: 52). Consequently, the tension between curbing immigration and children's 'universal rights' is particularly visible in the asylum process as this is the space for balancing the much-debated issue 
of maintaining Swedish welfare simultaneously as the right to asylum is protected. This administrative process begins at the Migration Agency as the first instance of three examining applications for asylum, and it is here that the emphasis of the asylum process shall happen.

In practice, both children and adults seeking refuge should be given an opportunity to state his or her point of view and to express an opinion about the circumstances invoked in the case in an oral procedure at the Agency. In a separate section of the Alien's Act children are guaranteed a right to be heard. They 'must be heard, unless this is inappropriate' and account is to be taken of what is said 'to the extent warranted by the age and maturity of the child' (Aliens Act 1:11). Further, in the implementation of the other sections of the Act, the best interests of the child should always be taken into consideration as an overarching principle (Aliens Act 1:10). In our case analysis, we discuss how these rights of asylum seeking children are displaced and how the Swedish asylum process becomes a key space of the 'deportation regime'-a concept we will now further address.

\section{Asylum in the Deportation Regime}

In practice, it is the asylum officials, as children's rights 'representatives of border policing' (De Genova 2010: 50), who balance children's rights against the deportation regime through 'technologies of citizenship' (Walters 2010). When doing so, specific childhoods are revealed, subject to cultural and temporal contingency, and embedded in time and space (Holzscheiter 2010: 10). More concretely, the officials apply rights in a context where deportability and humanist ideals are present, balancing tensions emerging in the process of including alien children into the sphere of ideal 'Swedish children' who embodies Swedish identities. In a broader community perspective, the officials are border guards involved in a protection of native children as 'natural Swedes' including their common ancestry, mutual kinship, and shared substance (De Genova 2010: 53f). As defenders of children's well-being, they are also navigating deeply contested meanings of childhood (Holzscheiter 2010: $84 \mathrm{ff}$.) and of children's rights (Liefaard and Doek 2015). Hence, manifestations of children's rights in the asylum process, where all applicants are potentially deportable, are part of technologies through which the people of Sweden as well as images of childhoods, are produced and re-produced. Our analysis of how children's rights are negotiated may also illustrate particularly sensitive issues in the nation-state that are managed within various authorities.

Nathalie Peutz and Nicholas De Genova (2010) discuss deportation as an indisputable recourse of administration that verifies and reaffirms state sovereignty. Deportation, they argue, is simultaneously a unified and global response to a world that is changing through transnational mobility, and an expression of a 'social political regime that manifests and endangers dominant notions of sovereignty, citizenship, public health, national identity, cultural homogeneity, racial purity, and class privilege' (Peutz and De Genova 2010: 2). In regards to the notion of sovereignty in the deportation regime, Galina Cornelisse (2010) shows the inconsistency of human rights discourse. In this global territorial order, in which international law is still the law for and by sovereign states alone, she argues, human rights have 'no role to play' and the interests of migrants 'do not need to be accounted for' (Cornelisse 2010: 113). While exploring 
detention, a different territorial space than our present focus, Cornelisse highlights a similar role of detention to asylum assessments in that they determine the inside from the outside and serves as a demonstration of effective control of national borders. An inverse argument is offered by Ayten Gündogdu who argues that the discretionary power of sovereign states have been curtailed through human rights law and the principle of non-refoulement, a development that has established the 'legal personhood of migrants' (2015: 107f). Nonetheless, Gündogdu states, the 'worrisome developments that make it more and more difficult to invoke human rights norms to contest deportation decisions' (Gündogdu 2015: 109) should be considered.

Further, De Genova introduces the notion of the 'spectacle of enforcement' (2002: 436) to illustrate how processes of separating the 'deportables' from those who should be included become natural, necessary and urgent. Rather than an issue of efficiency, deportation may be understood as a technology with a symbolic and indirect character, namely to reproduce a world order where individual rights are exclusively and pensively linked to citizenship. In a similar vein, Vicki Squire argues in relation to asylum in the UK that this may be understood as a primarily exclusionary practice caught up in a 'self-fulfilling cycle of restriction and control' (Squire 2009: 4), embedded with neoliberal restructuring and ambiguity of European integration. In a related study, Heaven Crawley (2009) points to the combination of restrictive measures of control and surveillance. This, she argues, constitutes a vicious circle affecting attitudes towards asylum. Crawley's analysis of attitudes to asylum and Squire's reflection on securitisation demonstrate how restrictive policy initiatives tend to reproduce images of asylum seekers as 'undeserving abusers' and hence in an ever-lasting circular logic justify restrictive initiatives.

In this article, we wish to connect this theoretical understanding of the deportation regime with the debate among children's rights scholars on the implementation of children's rights through a micro-oriented analysis of everyday practices in the Swedish asylum process. With regard to the implementation-debate our wish is to contribute to contextualized and critical discussions about the domestic effects (Holzscheiter 2010; Quennerstedt 2013) of the CRC through an in-depth analysis of the everyday 'standardised instrument of statecraft' (Peutz and De Genova 2010: 3). Here, inspired by Ton Liefaard and Jaap E. Doek's (2015) 'world-wide' mapping of the impact of the $\mathrm{CRC}$, we contribute with some pieces of the puzzle of what happens to and with children's rights in a dualistic state such as Sweden. Our study may also serve as a complement to, or understanding of, how initiatives to safeguard children's rights (Hodgkin et al. 2007), are constructed in contextual constructions of asylum law. Images of children as vulnerable and subordinated are, as we will show, sometimes put to a head in these local contexts. Whereas asylum is an under-research area in childhood studies this issue has been explored before in other contexts. An example is Jo Boyden and Joanna de Berry's (2004) discussion about alternative childhoods with a focus on children in armed conflicts.

Coming back to deportability, Klara Öberg argues that we can see the full meaning of this when exploring local contexts (Öberg 2015: 176). Deportability in the present study is understood as a continuous potentiality of the asylum process, since the consequence of legal assessments decide whether or not a person is granted residence in Sweden. Our local context is the space where those families 'who deserve Sweden' are separated from the 'non-deserving', where those who should be welcomed into the 
community are distinguished from those who shall be deported. Here, the rights of children play a particularly central role, this since if the parents' claims are not considered enough to grant asylum, children, as subjects to an extended catalogue of rights compared to their parents, could potentially enable deservingness for the whole family through their child-specific claims, if they are granted asylum.

\section{Methodological Considerations and Selection of Material}

For this empirical study, we collected 100 decisions from the Migration Agency and conducted ten interviews with 20 asylum officers. A random sample of decisions from the second half of 2013 was selected. We sought a balance between rejections and affirmative decisions. The latter was done in order to be able to describe whether there are similarities and differences between the two categories as regards children's right to have their best interests taken into consideration. In a first step, we collected a sample of cases that consisted of 30 decisions concerning children from Iran, Iraq and Lebanon, as well as 20 decisions concerning Syrian children. We also included 16 families' decisions regarding asylum-seeking children who were citizens of other EU countries and who had formally undergone a substantive examination of their asylum application. Furthermore, in order to find cases where the assessment of the best interests-principle had been drawn to extremes, 17 cases were identified where the children had been separated from their parents under the Act on the Care of Young Persons and Social Services Act. In this part of our study, first author went through the complete dossier of each case, which contained several decisions and notes on the situation of the children, including medical certificates, letters from school personnel and friends, as well as other various information describing the children's situation. The analysis in the following reading was inductive, guided by an open-ended search for specific child oriented units of analysis, i.e. formulations about the concerned children or about children's rights. We also asked what meaning, and underlying assumptions, that these formulations reproduced, about children's claims for protection and how these were relevant in the decision-making. In the process of determining the use of rights, we also asked what was left out. Overall, our analysis of the selected data was guided by an understanding of the context, i.e. the asylum procedure as an exclusionary process, but with an open ended search for meaning-making of children's claims and rights.

Besides this written material, second author conducted 10 semi-structured interviews with 20 employees ${ }^{1}$ working with asylum assessments in Sweden. Their perceptions of the balancing act tell something about how children's rights are applied. All 5 regional units that processed asylum applications at the time were contacted, and at least 1 interview was conducted in each place. 3 interviews had 1 interviewee, 5 had 2, and 2 interviews had 3 interviewees. The managers of each asylum unit assisted in the

\footnotetext{
${ }^{1}$ The interviewees had two different positions within the Migration Agency, and both groups were roughly equally represented in our sample. 'Decision makers' are responsible for the final decision of a case, but they make their decisions based on the detailed presentations of each case by a 'caseworker'. In practice, the decisions are the result of teamwork between a decision maker and a caseworker, and therefore the everyday practice of applying children's rights very much hinges on the actions of both these groups. Thus, in this text, we do not separate between the two but call them 'asylum officers' for the sake of simplicity.
} 
selection of participants, implying a risk that interviewees may have been chosen who would be less critical to the practices of the Migration Agency. This does however not seem to be the case since the interviewees expressed a wide variation in opinions about the themes discussed. They also brought up aspects of their work that they themselves experienced as problematic for children's rights. The quotes from the interviews and decisions in this article, as well as relevant Swedish legislation and policy included, have been translated as carefully as possible into English.

By combining multiple methods our methodological approach is a case of triangulation (Hussein 2015; Rothbauer 2008). More specifically, we explore the same phenomenon with two methodological approaches; a mapping of the actual outcome of children's rights in the assessments; a critical analysis of how the relevance of these rights is constructed among asylum officers when talking about their everyday work. Through this combination of methods, informed by previous studies in the field, we aim to increase our study's cogency. While different, both approaches nevertheless are designed to grasp the invention and re-invention of children's rights in a particular institutional setting. Through a combined approach, our expectation is to neutralize the flaws of one method and strengthen the other for more valid research results. We argue that an analysis of this kind of data enables a coherent understanding of the technologies that influence everyday constructions of children's rights. Another benefit of this mixed method approach is that the interviews were conducted during the later part of the document study and preliminary findings from the analysis of the decisions could therefore be discussed with the interviewees, which further enriched and contextualised the discussions that took place.

\section{Displacing Children's Rights Through Treacherous Assessments}

In this section, we present a micro-oriented analysis of written decisions in families' asylum cases and how decision makers at the Swedish Migration Agency discuss children's rights. As a starting-point the Agency's official approach to children's rights serves as a framework:

All children's cases are reviewed individually and 'the best interests of the child' is considered in all parts of the process. Child Rights Impact Assessments is the method the Agency uses for decision-making and all actions concerning children. This means that the Migration Agency investigates and assesses children's own grounds for asylum, including an oral conversation with children and/or their representatives. (Migrationsverket 2015: 111)

In relation to this official commitment, the asylum officers confirmed during the interviews an intention to have a child perspective in their decision-making, and they argued that this has gotten better over time, but time restraints and lack of knowledge often make things tough. Despite courses and seminars with external experts they find it difficult to apply children's rights as they primarily use the law and judicial praxis in their decision-making. These sources do not give much guidance in how to interpret children's rights in the individual balancing between restrictive migration politics and the best-interests principle. 
The discrepancy between the official image of the Agency and the descriptions among its personnel is one indicator that children's rights are a sensitive issue in the organisation. Asylum officers for the most parts do need, and many indeed want to, apply children's rights, while performing the balancing act of weighing children's interest against the state's interest of limiting migration. In the following sections, we analyse the practical outcomes of this difficult task of applying children's rights in the everyday work at the Migration Agency.

\section{Overlooking Children's Individual Claims Through a Circle of Neglect}

The first finding in our data that we argue tells something important about the application of children's rights at the Migration Agency was the practice of overlooking children's individual claims when they are seeking refuge together with their families. In the vast majority of cases in our study, children's asylum applications were assumed as being embedded in the parents' claims. The interviews pointed in the same direction. One of the interviewees told us that it is 'extremely rare' that children's asylum claims differ from their parent's claims in any substantial way. Yet, in our analysis of the written decisions, we found several examples where children's own grounds for asylum were brought up either by the children or their parents during the application process. These claims included children having witnessed their mother being raped or attempt suicide; children being arrested by the police because of their parent's political engagements; children being harassed at school and battered by teachers because of their ethnicity or honour related issues, but they were not considered in the final decisions. However, since the claims were mentioned in the notes from the interviews, even though they were not considered in the final decision, it was perceived in later stages of the process as if the children's claims had been assessed. In this way, children's rights were displaced through a process where an initial mentioning of a claim became seen throughout the process as a sign of that these claims also had been assessed even though no assessments were recorded as being made at any stage in the process. A recording of a claim became an assessment, and consequently they assumed that children's claims had been considered when actually the opposite was the case.

This process emerges in more detail when we look at the whole chain of actions and practices that we observed as part of the overlooking of the initial claims. The asylum officers expressed in the interviews how they lack appropriate knowledge about children's rights in general in their decision-making. This makes it hard for them to know what to do with the claims the children make, and to know what impact such claims could have on their decisions. Consequently, the officials are less likely to search for and ask about children's own experiences. Additionally, in the country of origin information (COI) used to assess the trustworthiness of asylum claims, there is a lack of information about children's specific circumstances. Together with the time pressure, the asylum officers are even less likely to try and look for such information and get updated on what kind of child specific claims for asylum that could be made. This lack of knowledge about child-related COI and child-specific claims makes the children's own stories less relevant to listen to for the asylum officers, and gives them fewer incentives to search for more knowledge about how to apply children's rights in their decision - and then we are back on square one. 


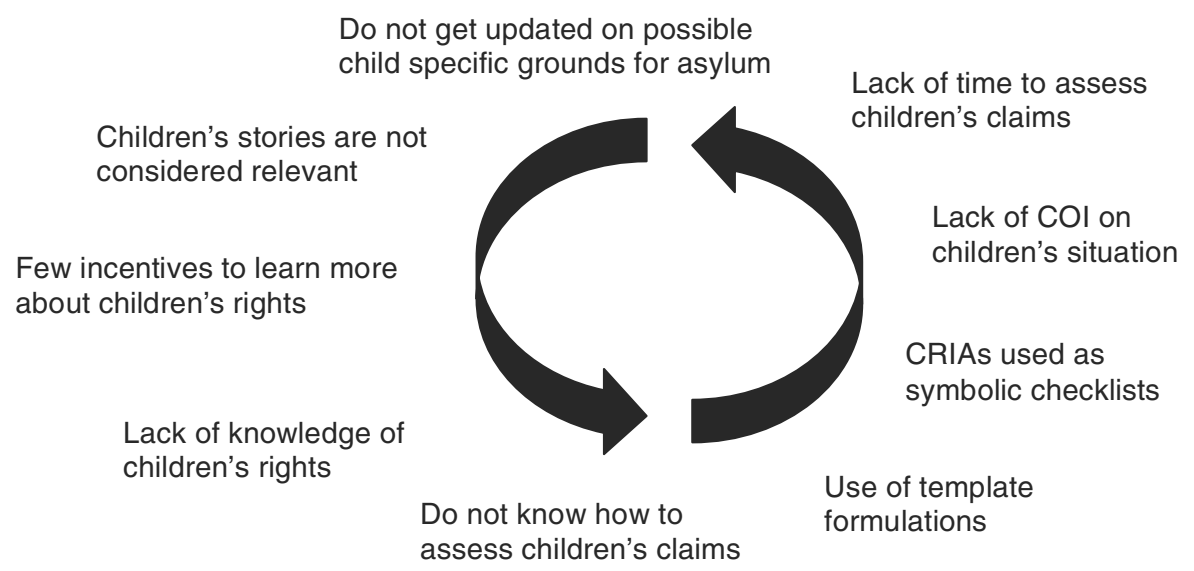

Fig. 1 Circle of neglect

Two additional aspects of this chain of actions and practices that we observed were the prevalent use of template formulations in the written asylum decision and the practical irrelevance of Child Rights Impact Assessments (CRIA). In the 30 decisions concerning families from Iran, Iraq and Lebanon for example, where half of the applications were rejected, it was clear that most assessments of 'the best interests of the child' were expressed in essentially identical ways. The pertinent sections of the Aliens Act, excerpts from judgments by the Migration Court of Appeal, and preparatory work of the Alien's Act were repeated in exact wording throughout practically all of the 30 decisions, both rejected and accepted applications. Still, the application of such articulations in the assessment of the child's situation remained unclear; the template formulations about children's rights only talked about their duty to assess these rights without also stating if and, if so, how this had been done.

Closely related to the use of templates is how the interviewees talked about their use of CRIA. Some younger officials described these as a checklist where the different elements they should go through during the assessment could be ticked off. Nevertheless, according to practically all of the interviewees, they ticked the boxes primarily because they were obliged to and not to actually assess the impact their decisions would have on children. Similarly, the decision-makers expressed in the interviews that they are aware of their duty to apply a child perspective, and the best-interests principle, in the asylum process of families. In practice, however, we observed that this came about mainly through template formulations. Both the use of template formulations and the practical irrelevance of CRIA in the decisions contribute to a displacement of children's rights in the decision-making. This seems to have given some decision makers a sense of actually having considered children's rights. Due to the legislation - and the Migration Agency's formal policy documents - symbolic paperwork tend to become an alibi for not taking children's rights seriously.

Through a combined analysis of these observations, we have constructed a figure that can describe these processes conceptually: we call it a 'circle of neglect' (see Fig. 1 below). The image of the circle highlights that these processes have no specific starting point and that they work together to keep children's own claims outside of the decisionmaking. These practices do not follow each other as neatly as they are portraid in Fig. 1, 
but are complex, intertwined and parallel processes. The figure is illustrative for an analytical understanding of how children's claims are displaced in practice. We understand the process visualised in the 'circle of neglect' as an interaction between everyday practices on the one hand and the deportation regime on the other, which results in the emergence of certain technologies.

For a deeper understanding of these practices, we want to point towards the direction into where children's rights can be understood to be displaced. According to the officials, children's positions are considered to a greater extent when they are unaccompanied or in assessments regarding whether humanitarian grounds for leave to remain are at hand, which we also saw in the decisions. However, a humanitarian ground for leave to remain is not based on the children's experiences in the country of origin but is rather an assessment of whether there are any other issues, such as bad health, or connection to the host society etc. that could be considered particularly distressing after an overall assessment. Consequently, assessments of humanitarian grounds for resident permit do not consider the individual claims for asylum that children in families make. The assessment of humanitarian grounds for leave to remain can be understood as the legal space to where children's rights in the asylum process are being displaced. Since children's rights are to some extent assessed in this part of the process, the asylum officers' logic conclusion is that children's rights are considered when their asylum applications are assessed, when they actually are only mentioned in the final stages of the decision-writing after the grounds for asylum or alternative grounds for protection have been rejected.

Several studies show that children do have individual grounds for asylum, and that these are neglected. Swedish Save the Children has on several occasions conducted studies of asylum decisions in Sweden, finding that children's rights are overlooked (Save the Children 2008, 2016a). It seems rather reasonable to assume that the children's own claims that differ from their parents are presumed not to have any relevance for the asylum assessment. In the present study we argue that the circle of neglect is useful if we want to understand how children's own claims for asylum are displaced in practice. In the following section, we will discuss a more intricate practice of displacing children's rights through negations.

\section{What Children's Best Interests Are Not}

The second finding of how children's rights are being displaced on a micro-level came about when we analysed the 100 decisions closely, attentive to the logic and language of the written arguments. Approaching the material inductively, i.e. moving from specific observations to broader generalizations and patterns, we were struck by a persistent use of negations, i.e. the stating of what something is not. In the decisions adopted by the Migration Agency, this could be formulated in terms of 'the decision is not in contradiction with the best interests of the child'; or 'it would not contradict the best interests-principle to go back home'; or 'it cannot be considered negative for the child to go back home with her/his parents'. These kinds of negating formulations did not include a consideration of what the child's best interest actually was in the individual cases. This contrasts directives from the UN Committee on the Rights of the Child (2013) that assessments of children's best interests need to be motivated and 
explained, and that the assessment process must be accounted for in any decision that is being made. To say that an act 'would not contradict the best interests-principle' or to say that a 'decision is not in contradiction with the best interests of the child' still leaves unanswered the question of what the best interests of the concerned child actually is. In our study of decisions and dossiers, as well as the interviews, a demarcation between what 'is' and what 'could not be considered to be in contradiction to' the child's best interests, is blurred.

This was reflected in our interviews through how the decision makers tended to shift between different formulations around children's rights. One asylum officer for example practically equated something that could not be considered 'the worst' for a child to also being 'the best' for the child:

Interviewee 1: I think it is quite tricky, that, 'the best interests of the child', because instinctively you want to think that, yeah, but it is always best for the child to stay in Sweden - Sweden is a safe country - but it does not have to be that way, it is not necessarily the worst for the child to actually return to one's country of origin, where you have relatives, a different social network, and where the parents have, like, roots and a society where they function - that can be the best interests of the child.

Another example of how children's best interests are considered in negative terms is the following quote by one of our interviewees who implicitly argued that to discuss what cannot be considered contrary to the best interests of the child is to actually consider what the best interests of the child is - to be with its parents:

Researcher: But the best interests of the child, that principle, don't you usually use it when you argue in your decisions?

Interviewee 2: Yeah, it is usually included, like: 'and therefore it would not contradict the best interests-principle if...'

Researcher: It is the negative form that is used then? Rather than: 'according to the best interests principle it should be argued...'

Interviewee 2: But that is what we say, 'in line with the best interest of the child being to be with its parents, to be in a country where they speak the language...'

One way to explain the above confusions as regards what the best interests principle is or is not, is to point to the fact that 'children's best interests' is a multifaceted and open concept. Both previous research (see for example Schiratzki 2005) and the asylum officers confirm the difficulties in actually applying what the best interests-principle implies. As noticed above, it was notoriously difficult for the asylum officers to relate to children's rights in their assessments. Negating formulations around children's rights were part of the template formulations that the decision makers used to include a discussion on how children's rights had (not) been assessed. One of the interviewees explained that she 'often felt a bit like a hypocrite' when using standardised formulations around children's rights. These exclusionary negating expressions have trickled 
down into the everyday practice of assessing asylum applications so that it is included in a majority of decisions where the children's rights are discussed.

These examples, together with the practices of using negations when considering children's rights in written decisions, tell us something about the possibilities of children's rights to have an impact in asylum assessments. The use of negations, and the kind of slipping and confusion demonstrated in the quotes, when talking about the assessment of the best interests-principle, is informed by and reproduces an underlying imagination of the asylum-seeking child as first and foremost potentially deportable, and secondly a rights bearer, we argue. One judicial basis of this potential deportability may be found in a formulation by the government in the preparatory work of the Alien's Act, where it is argued that staying in Sweden should not always be assumed as being the best interests of children, since such an approach disregards aspects of linguistic, cultural and national belonging. Such an 'ethnocentric view', the government argued, goes against the spirit of the CRC (Regeringen 1997: 225ff). In general, the government stated, it cannot be said that it would seriously damage a child's psycho-social development to accompany their children to another country.

\section{Children's Rights in the Deportation Regime}

We argue that negating children's rights has the consequence of turning assessments about children's rights into a question of what is the lowest possible level of protection, which mirrors the state's deportation regime. In the balancing act between migration control and children's rights, the practice of negations becomes a way for migration authorities to handle what is well known: that the consequence of the best interestsprinciple should reasonably be that more children gain residence permit than what is currently the case. In a system aiming for the maintenance of the nation state and a continuous exclusion of those who are not seen to belong, the asylum process and its officers are constrained to search for what circumstances a child can be sent back to without it 'being in contradiction with the best interests of the child'. Our analysis of the 'circle of neglect' and the use of negations shows that on a broad structural level there seems to be very little room for children's rights claiming in the deportation regime, and there is no room for children in the asylum process. The implication is a double displacement: Children in families seeking asylum are not adult enough to for their asylum claims to be considered, and not children enough to deserve qualification as bearer of children's rights in Sweden.

A straightforward assessment of what the best interests of these children would be is neither manageable nor meaningful, and perhaps also too painful to conduct in the milieu of the deportation regime. Talking about decisions as not being in contradiction with a child's best interests simply allows the asylum officers to get a feeling that they have formally conducted the necessary assessment of children's rights, while still being part of and reproducing the circle of neglect. Further linked to the negating approach is an unfounded assumption that was expressed in many of the decisions we analysed, which claimed that signs that it would be in the best interests of the child to stay in Sweden could constitute a 'too far-reaching interpretation of the children's best interests-principle'. Discussing this during our interviews, one official referred to the above preparatory work, which states that a too far-reaching interpretation could lead to a 
situation where being a child becomes a criteria for leave to remain on its own. The government says that many children, not the least from poor countries, would likely, in some sense have a better life if they came to Sweden, but it could be tempting to use children in cases where, as they say, 'the desire to migrate is strong but grounds for asylum does not exist' and in the case of irregular migrants for example, 'a burden of expectations and responsibility is put onto children, which hardly is compatible with a consideration of the best interests of children' (Regeringen 1997: 225 ff.). The government is in this way sending out a signal that any assessment suggesting that a child's best interests would be to stay in Sweden would potentially be a 'too far-reaching interpretation of the best interests-principle'. We argue that this logic is an effectual mean to limit migration through policy, since the signals have trickled down into the everyday practices and discourses at the Migration Board and consequently have become a central part of the deportation regime.

Highlighting practices of negating children's rights through analysing formulations in decisions and how asylum officers talk about asylum seeking children may seem as fault-finding. This is not our aim. We argue that an exploration of practices and discourses in the particular institutional framework of the asylum process where persons are on the border of the Swedish 'child-friendly' welfare state reveals intricate technologies that displace children's rights, which in turn says something important about the basis for rights-claims in general. Also, the use of the argument that a positive decision would in some cases mean a 'too far-reaching interpretation of the children's best interests-principle' without stating how this assessment has been made is another expression of how voluble statements are used to avoid stating clearly how the best interests of the child has actually been considered. As a consequence, the asylum officers seem to believe that they apply a child perspective in their decision-making when they actually are involved in practices displacing children's rights.

\section{An Exception That Confirms the Rule}

In our inductive analysis of the data, there were a few exceptions to the general practice of displacing children's rights. In one particularly interesting case, a presumption of norm harmony seemed to have been underlying the legal argumentation, i.e. Swedish law was interpreted in light of the principles in the CRC. We understand that the CRC can be used to justify negative decisions on asylum as well positive. However, here, we want to highlight one of these cases where asylum was granted to exemplify the potential of the CRC for asylum seeking children, in the deportation regime, but also as a case in point that this is currently limited to cases where humanitarian grounds for leave to remain are discussed.

The example concerned a 7-year-old girl born in a Middle Eastern country with a Christian father and Muslim mother. The family had gotten a rejection before but had stayed clandestinely in Sweden for 4 years until their rejection had been barred; the case we analysed was hence their second asylum process. The girl had adapted pungently to life in Sweden, the applicants argued, and while it was not clear in the decision whether she had made claims for individual asylum grounds, the written assessment clearly focused on her situation in light of the CRC. To begin with the decision contained a presentation of the relevant selections in the Alien's Act, i.e. the children's best interests 
paragraph in combination with a statement in the Act that children may be granted residence permits even if the circumstances that come to light do not have the same seriousness and weight that is required for a permit to be granted to adults. Hence, attention was given to the room provided by the legislator to apply the paragraph on particularly distressing circumstances more generously when children are at stake.

The Agency then referred to the very limited scope of the legislation to grant residence permit and the European Convention on Human Rights' article 8, which requires immigration authorities to take into account all the social and cultural ties that a person can have in a society - such as friends, education, work and membership of associations etc. Long stay may imply that the person had time to create strong ties to the country and, it was suggested, it is irrelevant whether the duration of stay was spent clandestinely or not in the country. It was furthermore emphasised that, as a child, it was not her own choice that the family stayed clandestinely in Sweden and therefore both unauthorized and authorized residence may in this light be considered in the decision through a so-called proportionality assessment.

Moreover, the Agency noted that the girl's parents as 'non-religious' have 'adopted to the Swedes' relation to religion'. The whole family speaks and writes Swedish and the girl does not speak the parents' mother tongue. These language skills have been important for the family's integration into Swedish society, the decision stated, and the family has little or no contact with their relatives in the country of origin. When the situation in the country of origin was reviewed, the CRC was used as a guideline in the following way:

In the assessment it should be considered if the child would have their basic needs met (cf. CRC 27), the child's family relationships, networks and other institutions (cf. 26, 31), educational opportunities (Article 28). [The applicant child] has, as already mentioned, in the current situation no relation to [country of origin]. She speaks Swedish better than her parents' native language.

In conclusion, found the Agency, it would be unreasonable under current circumstances to send the family back. It appears that the outcome in the case was clearly linked to the CRC-oriented analysis in combination with the family's adaptation to 'Swedish non-religious values' and language acquisition. In other words the girl and her family were considered worthy of a belonging to the Swedish nation. Thus, whereas an exception in terms of an enactment of children's rights, the case also displays dominant notions of sovereignty, national identity and cultural homogeneity, and confirms the inconsistency of rights-protection in the deportation regime. For example, the decision maker stated that the child had embodied a Swedish identity and 'nonreligious values'. Furthermore, the case, since leave to remain was entitled on humanitarian grounds, the case demonstrates that children's rights are heavily dependent of humanitarianism. Cornelisse's (2010) description of a human rights-inconsistency, where human rights have no political role to play, is thereby confirmed.

Finally, the case also exemplifies an embedded arbitrariness of the asylum system. One officer talked in our interview about how she tends to search for colleagues who would help her make the decision she wants to give, and she also discussed how different asylum officers get different reputations of being 'nice' or 'tough'. This arbitrariness is not unique for the Migration Agency, but exists in most public 
organisations, and, as the example above shows, the arbitrariness may work for the benefit of children. In the vast majority of cases though, the practice of using the paragraphs in the Alien's Act, into which the CRC has been transformed, to influence decisions in a positive direction is non-existent. Rather, the widespread practice of overlooking children's individual claims and the use of negations, as an expression of the incapacity to apply the best interests of the child in a coherent way, make sure that the arbitrariness in how children's rights are assessed at the Migration Agency does not jeopardize the deportation regime.

\section{Conclusion}

The meaning of a transnational treaty such as the CRC lies in what consequences it has when enacted in practice, and whether it may disrupt the prevailing world order by tying rights to personhood rather than legal status. This article demonstrates how children's rights are displaced in the everyday work at the Swedish Migration Agency through the overlooking of children's individual claims and the use of negations in relation to the principle of children's best interests. In our data children's rights were not used independently to enable more positive decisions for asylum seeking children, but were rather used to identify the lowest common denominator of how these children could be treated. Hence, the deportation regime permeates the asylum process through these technologies of displacement that we have discussed. Only when a child was also considered deserving of inclusion through its adaptation to Swedish values in assessments of humanitarian grounds the asylum officers took into consideration children's rights.

Everyday practices of discussing negative forms of children's rights, such as what could be considered not to be in contradiction with a child's best interests, result in a race to the bottom. Asylum officers ask just how bad the situation in the country of origin can be for them to still deport children and their families, rather than using children's rights to ask what kind of persecution or discrimination a specific child needs to be protected from. In a 'circle of neglect', this is further amplified in interrelated and parallel processes involving a lack of knowledge of children's rights and how to assess children's claims, together with a lack of time and limited country of origin information. The consequence is that the officials have no incentives to improve their knowledge and skills concerning asylum seeking children and consequently they reproduce an understanding of children's own claims as irrelevant. Also, even though the Swedish government agrees that many children would have a better life in Sweden, the perceived need to uphold a system of sorting out those who do not deserve to belong, and simultaneously apply the universal children's rights, came about through processes where the asylum officers used template decisions of negations to displace children's rights in their decisions.

These technologies of displacement are key to understanding both how children's rights are assessed in the everyday work at the Migration Agency and how the deportation regime is reproduced on the border of the state. By saying as little as possible through using standardised formulations of a negating character the officers perform children's rights by saying what they are not. As the quotes from our interviews show, this slip of thought is related to the negating language that persists at the Migration Agency, which has its roots in governmental policy. An inevitable consequence is that children's rights are hollowed out gradually. The technologies of displacement also involve a grand 
illusion where authorities officially claim to assess children's rights but instead do the reverse; displace them. Through a similar process, that this happens in everyday work. Further, also the legislature displaces children's rights through symbolically singling out the position of children, without handling the question of whether the CRC should trump the state's interests of keeping immigration numbers down.

The described practices furthermore hold back a potential of the CRC, which we have tried to uncover, to disrupt oppressive vehicles of power such as the deportation regime. This was partly done in the one case that stood out as an exception where residence permit was granted to a girl and her family, but only by also reproducing ideas of Swedishness and adaptation and arguing for humanitarian grounds for leave to remain rather than asylum. Further understandings of the role of children's rights in the current world, requires closer analysis of the sovereign nation states' prioritisation of migration control, even though it proves ineffective. Asylum at its core is part, of the exclusion of the many through the inclusion of the few and children's rights easily become revenue for upholding this violent system.

The desolate answer to whether an incorporation of the CRC into Swedish law can undo practices of displacement of children's rights is that it will probably not. Rather, an incorporation risks institutionalising and legitimising the problem of displacement as this happens through complex interrelated practices. Just as the asylum officers talk about considering children's rights when these are actually displaced, struggles for an incorporation may lead to 'more rights through more rules', which further displace children's rights. Focusing debates around children's rights on the legal framework supposed to protect them without also discussing what political struggles are needed on a wider scale, will shield the core of the problem; how rights, in particular children's rights, tend to reproduce exclusionary politics of asylum. In our study, we have seen no signs that incorporation would influence the strength or scope of the deportation regime. The double displacement that we have identified of the position of children seeking asylum with their families, where they are not considered adult enough for their asylum claims to be considered, and at the same time not children enough to deserve qualification as bearer of children's rights in Sweden, undermine the idea of children as specific rights-bearers.

Acknowledgements We wish to thank our colleague in Malmö, Dr Michael Strange, for his constructive comments on this work.

\section{Compliance with Ethical Standards}

Funding This work was financed by the Swedish Research Council (grant number 421-2012-683).

Conflict of Interest The authors declare that they have no conflict of interest.

Informed Consent Informed consent was obtained from all individual participants included in the study.

Open Access This article is distributed under the terms of the Creative Commons Attribution 4.0 International License (http://creativecommons.org/licenses/by/4.0/), which permits unrestricted use, distribution, and reproduction in any medium, provided you give appropriate credit to the original author(s) and the source, provide a link to the Creative Commons license, and indicate if changes were made. 


\section{References}

Andersson, H. E. (2012). 'International Conventions and the Regulation of Migration: The Convention on the Rights of the Child and Sweden'. The International Journal of Children's Rights, 20(1), 122-140. doi: 10.1163/157181811X570735

Arendt, H. (1973 [1951]). The origins of totalitarianism (Vol. 244). Houghton Mifflin Harcourt.

Åhman, K. (2011) Rättsutlåtande om inkorporation av Barnkonventionen. Uppsala Faculty of Law Working Paper 2011:4

Benhabib, S. (2004). The Rights of Others: Aliens, Residents and Citizens. Cambridge, UK: Cambridge University Press.

Boyden, J. (1997). 'Childhood and the policy makers: A comparative perspective on the globalization of childhood'. in A. James and A. Prout (eds) Constructing and Reconstructing Childhood, 2nd edn, pp. 190-229. London: Falmer Press.

Boyden, J. and de Berry, J. eds., (2004). Children and youth on the front line: Ethnography, armed conflict and displacement (Vol. 14). New York: Berghahn Books.

Carlshamre, A. et al. (2014), 'Gör barnkonventionen till lag', Dagen October third 2014, http://www.dagen. se/debatt/gor-barnkonventionen-till-lag-1.273397. Accessed 19 September 2016.

Cornelisse, G. (2010). 'Immigration Detention and the Territoriality of Universal Rights'. In The deportation regime: sovereignty, space, and the freedom of movement. N. De Genova, \& N. Peutz (Eds.). Duke University Press, pp. 101-122.

Crawley, H. (2009). Understanding and Changing Public Attitudes: Review of Existing Evidence from Public Information and Communication Campaigns. Executive Summary. Diana, Princess of Wales Memorial Fund.

De Genova, N. P. (2002). 'Migrant 'illegality' and deportability in everyday life'. Annual Review of Anthropology, 31, 419-447. doi: 10.1146/annurev.anthro.31.040402.085432

De Genova, N. (2010). 'The Deportation Regime: Sovereignty, Space, and the Freedom of Movement'. In N. De Genova \& N. M. Peutz (Eds.), The deportation regime: sovereignty, space, and the freedom of movement. Durham, NC: Duke University Press.

Emilsson, H. (2014) Sweden, in Triandafyllidou, A \& Gropas, R. (eds), European Immigration: A Sourcebook, Ashgate

Feijen, L., \& Frennmark, E. (2011). Kvalitet i svensk asylprövning - En studie av Migrationsverkets utredning av och beslut om internationellt skydd. UNHCR.

Flyvbjerg, B. (2001). Making social science matter why social inquiry fails and how it can succeed again. Oxford, UK; New York: Cambridge University Press.

Freeman, M. (2000). 'The future of children's rights'. Children \& Society, 14(4), 277-293. doi. 10.1111 j.1099-0860.2000.tb00183.x

Goodwin-Gill, G. S., \& McAdam, J. (2007). The refugee in international law (3rd ed). Oxford; New York: Oxford University Press.

Gündogdu, A., (2015). Rightlessness in an age of rights: Hannah Arendt and the contemporary struggles of migrants. Oxford University Press, USA.

Hodgkin, R., Newell, P. and UNICEF (2007). Implementation Handbook for the Convention on the Rights of the Child. https://www.unicef.org/publications/files/Implementation_Handbook_for_the_Convention_ on_the_Rights_of the_Child_Part_1_of_3.pdf. Accessed 2 December 2016.

Holzscheiter, A. (2010). Children's Rights in International Politics. The Transformative Power of Transnational Discourse. Gran Bretaña: Palgrave MacMillan.

Hussein, A. (2015). 'The use of triangulation in social sciences research : Can qualitative and quantitative methods be combined?' Journal of Comparative Social Work, 4(1).

Joppke, C. (1998). 'Why liberal states accept unwanted immigration'. World politics, 50, 266-293.

Joppke, C. (2001). 'The legal-domestic sources of immigrant rights the united states, germany, and the european union'. Comparative Political Studies, 34(4), 339-366. doi: 10.1177/0010414001034004001

Liefaard, T. \& Doek, J.E., 2015. Litigating the Rights of the Child. Netherlands: Springer.

Lundberg, A. (2011) The best interests of the child principle in Swedish asylum cases: Themarginalization of children's rights. Journal of Human Rights Practice, 3.1, 49-70.

McLeod, I. (2010) 'Critical perspectives on law'. In Ian McLeod, Legal Theory. Houndmills: Palgrave.

Migrationsverket (2015). Årsredovisning 2015 Migrationsverket. http://www.migrationsverket.se/download/18.2 d998ffc151ac3871593f89/1456151216443/Årsredovisning+2015.pdf. Accessed 19 September 2016

Noll, G. (2010). 'Why human rights fail to protect undocumented migrants'. European journal of migration and law, 12(2), 241-272. doi: 10.1163/157181610X496894 
Ottosson, L., and Lundberg, A. (2013) 'People out of place'? Advocates' negotiations on children's participation in the Asylum application process in Sweden. International Journal of Law, Policy and the Family, 27.2, 266-287.

Öberg, K. (2015). 'The production of deportability'. In Righard, E, Johansson, M, and Salonen, T, (eds.). Social Transformations in Scandinavian Cities: Nordic Perspectives on Urban Marginalisation and Social Sustainability.

Peutz, N. M., \& De Genova, N. (Eds.) (2010). 'Introduction'. In The deportation regime: sovereignty, space, and the freedom of movement. Durham, NC: Duke University Press.

Pobjoy, J. M. (2013). 'A Child Rights Framework for Assessing the Status of Refugee Children', in S. Juss and C. Harvey (eds.), Contemporary Issues in Refugee Law (Edward Elgar, 2013), 91-138.

Priban, J., (2002). 'Sharing the paradigms? Critical legal studies and the sociology of law', in An Introduction to Law and Social Theory, Oxford: Hart Publishing, 119-33.

Quennerstedt, A. (2013). 'Children's Rights Research Moving into the Future - Challenges on the Way Forward'. The International Journal of Children's Rights, 21(2), 233-247. http://doi.org/10.1163 /15718182-02102006

Regeringen (1997). Proposition 1996/97:25, Svensk migrationspolitik i globalt perspektiv. http://www. riksdagen.se/sv/Dokument-Lagar/Forslag/Propositioner-och-skrivelser/Svensk-migrationspolitik-i-glo_ GK0325/?text=true. Accessed 19 September 2016

Regeringen (2013). Kommittédirektiv 2013:35. http://www.regeringen.se/rattsdokument/kommittedirektiv/2013/03 /dir-201335. Accessed 19 September 2016

Regeringen (2016a). SOU 2016:19. Barnkonventionen blir svensk lag. http://www.regeringen. se/rattsdokument/statens-offentliga-utredningar/2016/03/sou-201619. Accessed 19 September 2016.

Regeringen (2016b) Regeringen föreslår åtgärder för att skapa andrum för svenskt flyktingmottagande, http:/www.regeringen.se/artiklar/2015/11/regeringen-foreslar-atgarder-for-att-skapa-andrum-for-svensktflyktingmottagande. Accessed 19 September 2016.

Regeringen (2016c). Prop. 2015/16:174 Tillfälliga begränsningar av möjligheten att få uppehållstillstånd $i$ Sverige. http://www.regeringen.se/contentassets/075968fdd8c94788977dba14bae16444/forslag-om-atttillfalligt-begransa-mojligheten-att-fa-uppehallstillstand-i-sverige-prop.-201516174. Accessed 19 September 2016. Accessed 19 September 2016.

Reynaert, D., Maria D. B., and Vandevelde S., (2012). 'Between 'believers' and 'opponents': critical discussions on children's rights.' The International Journal of Children's Rights 20.1: 1-15. doi: $10.1163 / 157181812$ X626417

Rothbauer, P. (2008) 'Triangulation'. In Given, Lisa (Ed.), The SAGE Encyclopedia of Qualitative Research Methods. Sage Publications. pp. 892-894

Save the Children (2008). Nytt system gamla brister. Barns egna asylskäl efter ett år med den nya instans-och processordningen. https://www.raddabarnen.se/Documents/vad-vi-gor/sverige/barn-pa-flykt/Nytt\%20 system\%20Gamla\%20brister.pdf. Accessed 19 September 2016

Save the Children (2016a). Barns egna asylskäl. Om rätten att bli sedd som individ. http://resourcecentre. savethechildren.se/sites/default/files/documents/rb_barns_egna_asylskal_160223_ref.pdf. Accessed 19 September 2016

Save the Children (2016b) Därför måste barnkonventionen bli lag. https://www.raddabarnen.se/vad-vigor/mer-om-vad-vi-gor/barns-rattigheter-samhallets-ansvar/barnkonventionen-som-lag. Accessed 19 September 2016

Schiratzki, J. (2005). Barnets bästa i ett mångkulturellt Sverige. Iustus.

Schmitt, C. (2005 [1922]). Political theology: four chapters on the concept of sovereignty (University of Chicago Press ed). Chicago: University of Chicago Press.

Shamseldin, L. (2012). 'Implementation of the United Nations Convention on the Rights of the Child 1989 in the care and protection of unaccompanied asylum seeking children: Findings from empirical research in England, Ireland and Sweden'. The International Journal of Children's Rights, 20(1), 90-121. doi: 10.1163/157181811X570717

Soysal, Y. N. (1994) Limits of citizenship: Migrants and postnational membership in Europe. Chicago University of Chicago Press.

Squire, V. (2009). The Exclusionary Politics of Asylum. Palgrave Macmillan UK.

Stern, R. \& Jörnrud, M. (2011) Barnkonventionens status. En utvärdering av för-och nackdelar med barnkonventionen som svensk lag [The Child Right Conventions Status. An Evaluation of the Pros and Cons of the Convention as Swedish Law]. Lund: Raoul Wallenberginstitutet för mänskliga rättigheter och humanitär rätt. 
UN Committee on the Rights of the Child. (2013). General comment No. 14. On the right of the child to have his or her best interests taken as a primary consideration (art. 3, para. 1).

UNHCR (2015). Worldwide displacement hits all-time high as war and persecution increase. One in every 122 humans is now either a refugee, internally displaced, or seeking asylum. http://www.unhcr. org/news/latest/2015/6/558193896/worldwide-displacement-hits-all-time-high-war-persecution-increase. html. Accessed 19 September 2016

UNICEF (2016) Gör barnkonventionen till lag [campaign], https://unicef.se/barnkonventionen. Accessed 19 September 2016

Van Bueren,G., (1999). 'Combating Child Poverty-Human Rights Approaches.' Human Rights Quarterly 21.3: 680-706.

Walters, W. (2010). 'Deportation, Expulsion, and the International Police of Aliens'. In N. De Genova \& N. M. Peutz (Eds.), The deportation regime: sovereignty, space, and the freedom of movement. Durham, NC: Duke University Press. 